Additional services for The Classical Review:

Terms of use : Click here

R. Melville (trans.): Lucretius: On the Nature of the Universe (with introduction and notes by $D$. and P. Fowler). Pp. xxxiv + 275. Oxford: Clarendon Press, 1997. Cased, £45. ISBN: 0-19815097-0.

R. W. Sharples

The Classical Review / Volume 51 / Issue 02 / October 2001, pp 396 - 397

DOI: 10.1093/cr/51.2.396, Published online: 25 April 2006

Link to this article: http://journals.cambridge.org/abstract_S0009840X01002591

How to cite this article:

R. W. Sharples (2001). The Classical Review,51, pp 396-397 doi:10.1093/cr/51.2.396

Request Permissions : $\underline{\text { Click here }}$ 


\section{R. Melville (trans.): Lucretius: On the Nature of the Universe (with introduction and notes by D. and P. Fowler). Pp. xxxiv + 275. Oxford: Clarendon Press, 1997. Cased, £45. ISBN: 0-19815097-0.}

Lucretius' poem is almost unique among didactic poems in the way in which the poetry reinforces the content, rather than functioning as decoration for which the content provides the pretext. If the conveying of Epicurus' message had been left to his own and his followers' prose, it may be questioned whether it would have had the same impact. I say 'almost unique' because the importance and quality of Parmenides' use of verse has sometimes been insufficiently appreciated, and we would be able to judge Empedocles better if more of his poem survived.

Sir Ronald Melville translated Lucretius' poem into English verse 'between May 1994 and November 1995, working for a couple of hours in the evening after dinner, with a glass of port at hand in case I got stuck' (p. xxxv). To accompany his translation Don and Peta Fowler have provided an excellent thirty-five-page introduction and notes which, though relatively brief (fifty-eight pages of notes to 215 pages of the translation) and concentrating on explanation rather than on criticism of the argument, are particularly informative on the ancient literary parallels.

The translation is into unrhymed English iambic pentameters, with relatively short sentence structures (five lines or so) whose ends tend to coincide with line-breaks. This indeed follows Lucretius' own practice; but when applied to the English pentameter rather than to the Latin hexameter, it seems, to me at least, to lose something of the relentless urgency and onward movement of Lucretius' verse (or Juvenal's, or Milton's), though I am no poet and should not venture to criticize. Sometimes indeed the grandeur of Lucretius is captured:

Therefore his lively intellect prevailed

And forth he marched, advancing onwards far

Beyond the flaming ramparts of the world,

And voyaged in mind throughout infinity,

Whence he victorious back in triumph brings

Report of what can be and what cannot

And in what manner each thing has a power

That's limited, and deep-set boundary stone.

This is the mirror nature holds for us

To show the face of time to come, when we

At last are dead. Is there in this for us

(C) Classical Association, 2001 
Anything horrible? Is there anything sad?

Is it not more free from care than any sleep? (3.974ff.)

'When the world shook with the tumult of war' (3.834) and 'everything we see is doubled by our vision' (4.449) have only four stresses, not five. 'must be dispersed, as is most necessary' for necessest . . . discutiant (1.146-8) loses the brevity of the Latin in order to complete the English line.

The translation omits 4.45-50 and transposes 44 to follow 53. 51-3 should be omitted as well (thus removing the need for transposition); cortex is used in different ways in 43 (unless one emends to corpore with Lambinus) and in 51, and as David Sedley has now shown in Lucretius and the Transformation of Greek Wisdom (Cambridge, 1998), pp. 40-1 and n. 16, 51 represents an earlier stage in the development of Lucretius' terminology. (The marginal numbers 41-43, 51-53, and 44 in the translation are all placed one line too low.) The commentary rightly suggests that $1247-51$ should be placed at the very end of the poem, but this has not actually been done in the translation.

The Introduction sets out the historical context in which Lucretius' poem was composed. It rightly notes that the use of metaphor in scientific explanation is not confined to Lucretius or to antiquity (p. xxv), and emphasizes the complexity of the appeal to simplicity (p. xxviii). The identification of desire for sex as natural but not necessary (p. xx, quoting fr. 496 Usener: in fact 456, as rightly at 248) is questionable; it may be, in the terms of Epicurus' Letter to Menoeceus 127 , necessary 'for freedom from bodily disturbance' though not 'for life itself'. See the present reviewer's Stoics, Epicureans and Sceptics (London, 1996), p. 143 n. 6, and references there.

The book was published in 1997 (the delay in the appearance of this review is not the fault of the present reviewer). It could not therefore note two subsequent events, one positive in its effects for Lucretian studies and one negative. The first was the appearance of David Sedley's book already mentioned, now fundamental for all study of the poem, its composition, and its relation to Epicurus' own writings. The latter was, of course, Don Fowler's untimely death, which has deprived the subject of one of its leading interpreters.

University College London

R. W. SHARPLES 